Jurnal Selulosa Vol. 10 No. 1 Juni 2020 Hal. 1 - 8

JURNAL SELULOSA

e-ISSN: $2527-6662$

p-ISSN: $2088-7000$

\title{
Sintesis Micro-Fibrillated Cellulose dari Serat Tandan Kosong Sawit dengan Hidrolisis Asam Oksalat
}

\author{
Rizka Karima, Evana Yuanita, Bunda Amalia, Agustina Arianita, Tiara Mailisa, Bumiarto Nugroho \\ Balai Besar Kimia Kemasan, Jl. Balai Kimia No. 1 Pasar Rebo, Jakarta Timur, Indonesia
}

Diterima : 12 Februari 2020, Revisi akhir : 8 Mei 2020, Disetujui terbit : 30 Juni 2020

\section{Synthesis of Micro-Fibrillated Cellulose from Oil Palm Empty Fruit Bunches Fiber with Oxalic Acid Hydrolysis}

\begin{abstract}
Oil Palm Empty Fruit Bunches (OPEFB), which is a solid waste from the palm oil processing industry, has a high availability in Indonesia, and it contains a lot of cellulose. Microfibrillated cellulose (MFC) can be produced from OPEFB fiber. This work's objective was to synthesize MFC from fibers of OPEFB through the process of alkalization, bleaching process, and the hydrolysis process using an oxalic acid solution. The procedure began chopped fiber until 60 mesh, and alkalization process of pulping OPEFB in the reactor using $4 \% \mathrm{NaOH}$ at the temperature of $90{ }^{\circ} \mathrm{C}$ for 2 hours. It continued with the addition of $20 \% \mathrm{H}_{2} \mathrm{O}_{2}$ at room temperature for 2 hours. The hydrolysis process is carried out using an oxalic acid $5 \%$ at temperature of $80^{\circ} \mathrm{C}$ for 1 hour. MFC was analyzed using Fourier Transform Infrared Spectroscopy (FTIR), X-Ray Diffraction (XRD), Thermal Gravimetric Analysis (TGA), and Field Emission Scanning Electron Microscopy (FESEM). The FTIR analysis showed that the quantitative result also confirmed a decrease in lignocellulose content. XRD result showed an increase in the value of crystallinity. TGA results showed that hydrolysis using oxalic acid can increase the area of thermal degradation, and FESEM results showed there is a decreasing diameter of fiber from $400 \mu \mathrm{m}$ to $10 \mu \mathrm{m}$. From the results of this study, when viewed from the results of crystallinity, thermal properties, and size of the fiber diameter, the hydrolysis process using 5\% oxalic acid is a good process for making MFCs from TKS fibers.
\end{abstract}

Keywords: micro-fibrillated cellulose, OPEFB, oxalic acid

\section{Abstrak}

Tandan Kosong Sawit (TKS) merupakan limbah padat dari industri pengolahan kelapa sawit yang melimpah di Indonesia dan mengandung banyak selulosa. Microfibrillated cellulose (MFC) dapat diproduksi dari serat TKS. Tujuan dari penelitian ini adalah untuk mensintesis MFC dari serat TKS melalui proses alkalisasi, pemutihan dan hidrolisis. TKS dicacah dan dihaluskan hingga berukuran 60 mesh untuk proses pembuatan pulp TKS. Proses alkalisasi dilakukan dalam reaktor menggunakan $4 \% \mathrm{NaOH}$ pada suhu $90{ }^{\circ} \mathrm{C}$ selama 2 jam dan dilanjutkan dengan proses pemutihan mengunakan $20 \% \mathrm{H}_{2} \mathrm{O}_{2}$ pada suhu kamar selama 2 jam. Kemudian proses hidrolisis dilakukan menggunakan asam oksalat $5 \%$ pada suhu $80^{\circ} \mathrm{C}$ selama $1 \mathrm{jam}$. MFC yang dihasilkan dianalisis menggunakan Fourier Transform Infrared Spectroscopy (FTIR), X-Ray Difraction (XRD), Thermal Gravimetric Analysis (TGA) dan Field Emission Scanning Electron Microscopy (FESEM). Hasil analisis FTIR menunjukkan bahwa adanya penurunan kadar lignoselulosa yang dikonfirmasi juga oleh hasil uji kuantitatif kadar lignin. Hasil uji XRD menunjukkan peningkatan nilai kristalinitas. Hasil uji TGA menunjukkan hidrolisis menggunakan asam oksalat 5\% dapat meningkatkan area degradasi termal dan hasil FESEM menunjukkan telah terjadi proses fibrilisasi serat dan penurunan diameter ukuran serat dari $400 \mu \mathrm{m}$ menjadi $10 \mu \mathrm{m}$. Dari hasil penelitian ini, jika dilihat dari hasil kristalinitas, sifat termal dan ukuran diameter serat, proses hidrolisis menggunakan asam oksalat $5 \%$ adalah proses yang baik untuk pembuatan MFC dari serat TKS.

Kata kunci: micro-fibrillated cellulose, TKS, asam oksalat 


\section{Pendahuluan}

Indonesia memiliki sumber daya alam yang melimpah, salah satu potensinya ada di sektor kelapa sawit. Tandan Kosong Sawit (TKS) adalah limbah padat dari industri pengolahan kelapa sawit yang memiliki ketersediaan tinggi. TKS adalah produk sampingan dari perkebunan kelapa sawit yang persentasenya sekitar 23\% dari berat tandan kelapa sawit segar. Sejauh ini, hanya $10 \%$ dari TKS yang telah diaplikasikan. Beberapa pengembangan telah dilakukan untuk meningkatkan aplikasi dan nilai ekonomi TKS, salah satu caranya adalah dengan mengaplikasikan serat TKS untuk kebutuhan industri. Selulosa adalah salah satukandungan serat dari TKS dengan persentasenya sekitar 30-40\% (Dewanti, 2018). Selulosa TKS dapat digunakan untuk berbagai keperluan. Micro-fibrillated Cellulose (MFC) adalah salah satu bentuk selulosa yang dapat diaplikasikan sebagai bahan pengisi dalam industri pembuatan plastik.

MFC adalah subkelompok serat selulosa skala mikro yang berpotensi digunakan sebagai bahan penguat dan meningkatkan kekuatan ikatan antar serat (Rezayati Charani et al., 2013). Pembuatan MFC relatif mudah dan berpeluang untuk diteliti lebih dalam. Selain itu, penggunaan MFC telah ditemukan sebagai lapisan permukaan pada lembaran kertas untuk mengurangi permeabilitas oksigen (Yasa et al., 2020). Beberapa publikasi akhir-akhir ini menunjukkan bagaimana MFC dapat dimanfaatkan untuk berbagai keperluan, misalnya untuk nanokomposit (Syverud and Stenius, 2009). MFC memiliki banyak daerah kristal karena struktur fibrilarnya dan memiliki banyak ikatan hidrogen yang membentuk struktur kristal tiga dimensi. Namun, MFC tidak dapat terdispersi secara homogen dalam media nonpolar seperti pelarut organik karena sifat selulosa yang hidrofilik. Beberapa upaya telah dilakukan untuk membuat selulosa kompatibel dengan matriks polimer non-polar (Lavoine et al., 2012).

Beberapa metode dapat digunakan untuk preparasi MFC, seperti perlakuan mekanik, perlakuan kimia, dan perlakuan enzimatik. Preparasi MFC dengan perlakuan kimia dapat meningkatkan sifat fisik dan penampakan MFC. Perlakuan kimia bertujuan untuk menghasilkan selulosa murni, seperti pulp selulosa yang diputihkan, yang dapat diproses lebih lanjut. Sebuah penelitian mengisolasi MFC dari serat Arenga pinnata "ijuk" telah dilakukan dengan metode multistage. Serat diperoleh melalui tahapan proses alkalisasi dengan $\mathrm{NaOH}$, oksidasi dengan natrium hipoklorit $(\mathrm{NaClO})$, dan hidrolisis dengan asam sulfat. Hasilnya menunjukkan bahwa lignin dan hemiselulosa dapat dihilangkan. Setelah perlakuan, dimensi MFC yang diekstraksi menjadi lebih kecil dan kristalinitasnya lebih tinggi daripada tanpa perlakuan (Yuanita et al., 2015).

Hidrolisis asam kuat adalah metode yang umum digunakan dan dapat menghemat waktu, akan tetapi memiliki masalah lingkungan dan hasil produksi yang rendah. Hidrolisis dalam less harsh condition menggunakan asam padat dan asam organik dapat memperoleh hasil yang lebih tinggi. Asam oksalat adalah asam organik lemah. Asam oksalat memiliki nilai pKa yang lebih tinggi dan dengan demikian memberikan kondisi asam yang lebih ringan daripada asam mineral seperti asam sulfat ( $\mathrm{Xu}$ et al., 2017). Dalam penelitian ini, MFC diisolasi dari serat TKS menggunakan asam oksalat 5\% pada suhu $80^{\circ} \mathrm{C}$ selama $1 \mathrm{jam}$, konsentrasi asam oksalat yang digunakan hanya 5\% karena telah dilakukan penelitian pendahuluan yang menunjukkan bahwa konsentrasi lebih dari 5\% menyebabkan kondensasi lignin. Kemudian serat yang dihasilkan dikarakterisasi dengan menggunakan Fourier Transform Infrared Spectroscopy (FTIR) mengetahui, X-Ray Difraction (XRD), Thermal Gravimetric Analysis (TGA) dan Field Emission Scanning Electron Microscopy (FESEM) untuk mengetahui perbedaan karakter serat sebelum dan setelah diberikan perlakuan hidrolisis asam. Penelitian ini bertujuan mensintesis MFC dari serat TKS melalui proses alkalisasi dan hidrolisis asam oksalat.

\section{Bahan dan Metode}

Bahan yang digunakan adalah serat TKS yang diperoleh dari limbah industri minyak kelapa sawit, bahan - bahan kimia diantaranya $\mathrm{NaOH} 4 \%$, $\mathrm{H}_{2} \mathrm{O}_{2} 20 \%$ dan asam oksalat $5 \%$.

\section{Proses Alkalisasi}

Serat TKS dicacah dan dihaluskan hingga ukuran 60 mesh. Serat dan larutan $\mathrm{NaOH}$ $40 \%$ kemudian dimasukkan ke dalam reaktor dengan perbandingan $5 \%$ berat serat/volume larutan. Reaktor dipanaskan hingga suhu $90^{\circ} \mathrm{C}$ selama 2 jam. 


\section{Proses Pemutihan (Bleaching)}

Setelah proses alkalisasi selesai, dilakukan penyaringan, pencucian dan penetralan serat dengan menggunakan air suling. Serat selanjutnya direndam dalam larutan $\mathrm{H}_{2} \mathrm{O}_{2}$ dengan perbandingan $5 \%$ berat serat/volume larutan selama 2 jam.

\section{Proses Hidrolisis}

Serat putih selanjutnya dihidrolisis menggunakan asam oksalat 5\% dan dipanaskan pada suhu $80^{\circ} \mathrm{C}$ selama $1 \mathrm{jam}$. Setelah itu, serat disaring, dicuci, dan dinetralkan dengan air suling.

\section{Fourier Transform Infrared Spectroscopy (FTIR)}

Spektra FTIR diuji pada alat FTIR merek Nicolet Is5 pada panjang gelombang $400-4000 \mathrm{~cm}^{-1}$.

\section{Thermo Gravimetric Analisys (TGA)}

Analisis TGA dilakukan menggunakan Linseis TG-HDSC. Analisis termal dilakukan dalam atmosfer nitrogen di bawah laju aliran $4 \mathrm{nl} / \mathrm{jam}$ menggunakan wadah alumina. Massa rata-rata $10 \mathrm{mg}$ sampel dengan laju pemanasan $10 \mathrm{~K} /$ menit dengan suhu analisis antara $20^{\circ} \mathrm{C}$ hingga $500^{\circ} \mathrm{C}$.

\section{X-Ray Diffraction (X-RD)}

Profil difraksi ekuator X-Ray dari serat dikumpulkan oleh XRD D8 Advace Bruker (Jerman) menggunakan radiasi $\mathrm{CuK} \alpha$ pada tegangan operasi dan arus masing-masing 40 $\mathrm{kV}$ dan $20 \mathrm{~mA}$. Intensitas difraksi dicatat antara 5 dan $80^{\circ}$ (rentang $2 \theta$ angle).

\section{Field Emission Scanning Electron Microscopy (FESEM)}

Analisis morfologi serat dilakukan menggunakan alat FE-SEM FEI Inspect F50 dengan lensa WD 12,5 $\mathrm{mm}$ dan pembesaran pada 100, 250, 500, 1000, dan 5000 kali.

\section{Hasil dan Pembahasan}

\section{Proses Preparasi dan Hidrolisis Serat}

Serat TKS dalam penelitian ini diekstraksi dengan menggunakan $\mathrm{NaOH}$ dan diikuti oleh tahap kedua menggunakan asam oksalat 5\%.
Serat TKS direaksikan dengan $\mathrm{NaOH}$ untuk menghasilkan serat selulosa coklat, warna serat berubah menjadi coklat atau disebut dekolorasi. Dekolorasi disebabkan oleh proses reaksi oksidasi yang terjadi antara gugus fenolik dan udara atau disebut reaksi delignifikasi (Tristantini, Dewanti and Sandra, 2017). Proses pemutihan menggunakan $\mathrm{H}_{2} \mathrm{O}_{2}$ diperlukan untuk menghilangkan warna coklat, dan juga dapat menghilangkan kotoran yang tidak diinginkan (Abraham et al., 2011). Untuk meningkatkan kemurnian selulosa dan penghilangan gugus $\mathrm{OH}$, dilakukan ekstraksi tahap kedua atau proses hidrolisis dengan asam oksalat. Keuntungan dari proses hidrolisis dengan asam lemah adalah proses netralisasi yang cepat, sedangkan kekurangannya adalah proses hidrolisis kemungkinan tidak sempurna dan dikhawatirkan akan terjadi produk samping yang tidak diinginkan (Osvaldo, Panca Putra and Faizal, 2012). Proses hidrolisis asam dapat terjadi karena dua faktor: konsentrasi atau bobot jenis asam dan suhu (Burhani et al., 2017). Kebanyakan serat alam adalah polimer yang memiliki amorf dan kristalin. Lignin dan hemiselulosa merupakan bagian amorf. Oleh karena, itu hidrolisis asam dilakukan untuk menurunkan bagian amorf (Ismojo et al., 2017).

\section{Fourier Transform Infrared Spectroscopy (FTIR)}

Spektrum serapan antara 3400-2400 $\mathrm{cm}^{-1}$ merupakan spektrum gugus atau ikatan $-\mathrm{OH}$ (Abraham et al., 2013). Gambar 1 menunjukkan bahwa puncak di area streaching - $\mathrm{OH}$ masih terlihat. Hal ini menunjukkan bahwa proses hidrolisis tidak sempurna. Karena asam oksalat adalah asam lemah sehingga $\mathrm{OH}^{-}$hanya sedikit yang ditarik oleh $\mathrm{H}^{+}$. Karena proses hidrolisis yang terjadi masih belum sempurna maka masih dapat dimungkinkan penyerapan uap air di udara oleh serat yang dihasilkan, oleh karena itu untuk mencegah penyerapan uap air tersebut, perlu dilakukan pengeringan dengan oven vakum.

Serapan -OH juga menunjukkan keberadaan lignin karena spektrum FTIR untuk lignoselulosa dibagi menjadi dua bagian, yaitu pada area getaran peregangan - $\mathrm{CH}$ dan $-\mathrm{OH}\left(4000-2700 \mathrm{~cm}^{-1}\right)$ dan sidik jari (1800-800 $\mathrm{cm}^{-1}$ ) (Abraham et al., 2013). Hasil FTIR pada Gambar 1 menunjukkan puncak ketajaman pada daerah lignoselulosa menurun. Hal ini menunjukkan bahwa lignin dapat larut dalam asam oksalat dan proses penghilangan atau delignifikasi lignoselulosa 


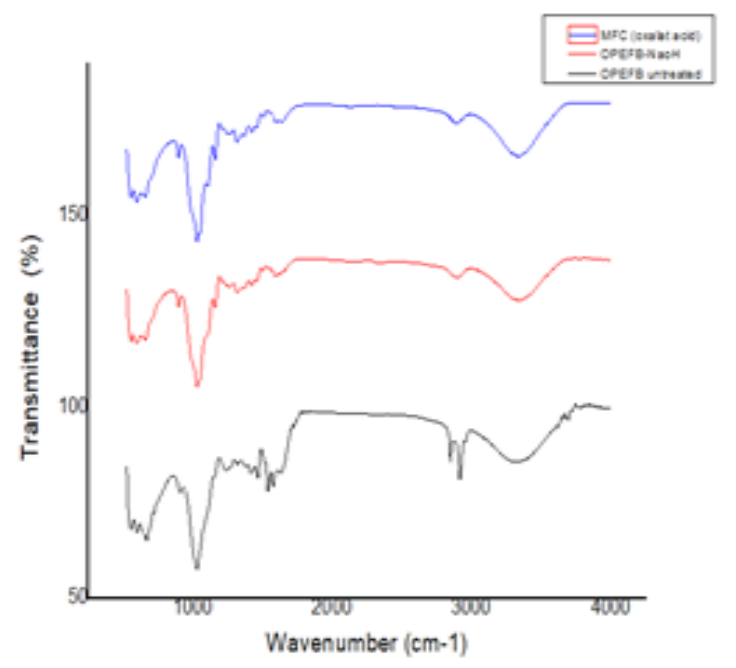

Gambar 1. Spektrum FTIR dari Serat TKS tanpa Perlakuan, Perlakuan $\mathrm{NaOH}$, dan Hidrolisis Asam Oksalat (MFC)

telah terjadi. Hal ini juga diperkuat oleh hasil uji kuantitatif yang ditunjukkan pada Tabel 1 yang menunjukkan terjadi penurunan kadar lignin dari $32,45 \%$ menjadi $10,67 \%$. Area spektrum pada kisaran $2900 \mathrm{~cm}^{-1}$ adalah streaching area C-H dalam molekul selulosa, puncak ketajaman pada area ini berkurang yang mengindikasikan bahwa ikatan glikosidik telah dipecah menjadi metil atau metil selulosa (Barlianti et al., 2015). Struktur kristal selulosa dicirikan oleh penampilan puncak absorpsi pada bilangan gelombang $1430 \mathrm{~cm}^{-1}$ dan penyerapan struktur amorf pada $898 \mathrm{~cm}^{-1}$ (Ahmad et al., 2015). Dalam penelitian ini, puncak serapan pada $1430 \mathrm{~cm}^{-1}$ meningkat dengan proses hidrolisis oleh asam oksalat dan penyerapan pada $898 \mathrm{~cm}^{-1}$ cenderung stabil yang menunjukkan peningkatan tingkat kristalinitas yang dapat dikonfirmasi melalui pengujian XRD.

\section{Thermo Gravimetric Analisys (TGA)}

Hasil analisis TGA (Gambar 2) menunjukkan telah terjadi beberapa tahap degradasi dan penyusutan bobot dari sampel TKS tanpa perlakuan dan TKS yang dihidrolisis dengan asam oksalat (MFC). Pada penelitian ini dilakukan pada suhu $20^{\circ} \mathrm{C}-500^{\circ} \mathrm{C}$ dan telah terjadi beberapa tahap degradasi komponen atau penurunan bobot sampel dari TKS dan MFC. Degradasi pertama terjadi penurunan berat molekul yang kecil pada kisaran suhu analisis 20-110 ${ }^{\circ}$, merupakan proses kehilangan uap
Tabel 1. Hasil Analisis Kadar Lignin dan Total Selulosa

\begin{tabular}{|c|c|c|c|c|}
\hline \multirow[b]{2}{*}{ No } & \multirow[b]{2}{*}{ Parameter } & \multirow[b]{2}{*}{ Satuan } & \multicolumn{2}{|c|}{ Sampel } \\
\hline & & & $\begin{array}{c}\text { TKS } \\
\text { (sebelum } \\
\text { preparasi) }\end{array}$ & $\begin{array}{c}\text { MFC } \\
\text { (Hidrolisis } \\
\text { As. Oksalat } \\
5 \% \text { ) }\end{array}$ \\
\hline 1 & Lignin & $\%$ & 32,45 & 10,67 \\
\hline 2 & $\begin{array}{l}\text { Total } \\
\text { Selulosa }\end{array}$ & $\%$ & 49,74 & 81,20 \\
\hline
\end{tabular}

air atau senyawa lainnya dengan berat molekul rendah (Abraham et al., 2013). Hal ini sejalan dengan hasil analisis FTIR yang masih memiliki banyak komponen -OH. Degradasi tahap kedua adalah serat TKS mengalami penurunan berat secara dramatis pada suhu $260^{\circ} \mathrm{C}$ hingga $360^{\circ} \mathrm{C}$. Sementara berat MFC menurun secara dramatis terjadi pada suhu $280^{\circ} \mathrm{C}$ hingga $370^{\circ} \mathrm{C}$ seperti yang terlihat pada Gambar 2.

Penurunan berat MFC ini lebih lama karena polimer selulosa diklasifikasikan sebagai tahan terhadap panas. Kerusakan serat oleh panas dimulai dengan oksiselulosa yang berlanjut dengan degradasi, pembentukan karbon dioksida dan air yang menguap dan akhirnya hanya abu yang tersisa (Syahbanu, Anugraini and Melati, 2018). Hal ini juga menunjukkan bahwa MFC memiliki tingkat kristalinitas, orientasi polimer, dan bentuk fibril yang lebih tinggi dari pada serat TKS tanpa perlakuan (Chen et al., 2011). MFC yang terbuat dari serat TKS dengan proses hidrolisis asam

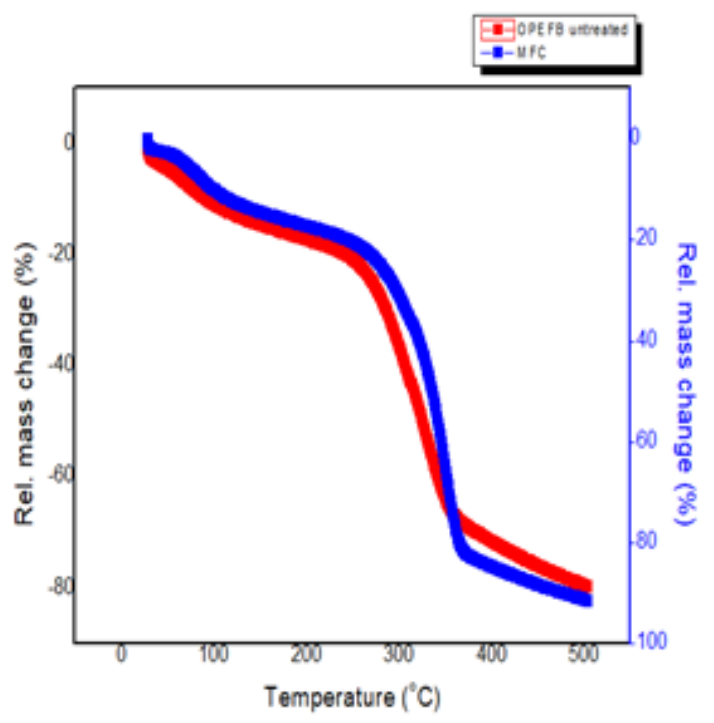

Gambar 2. Kurva TGA Serat TKS dan MFC 


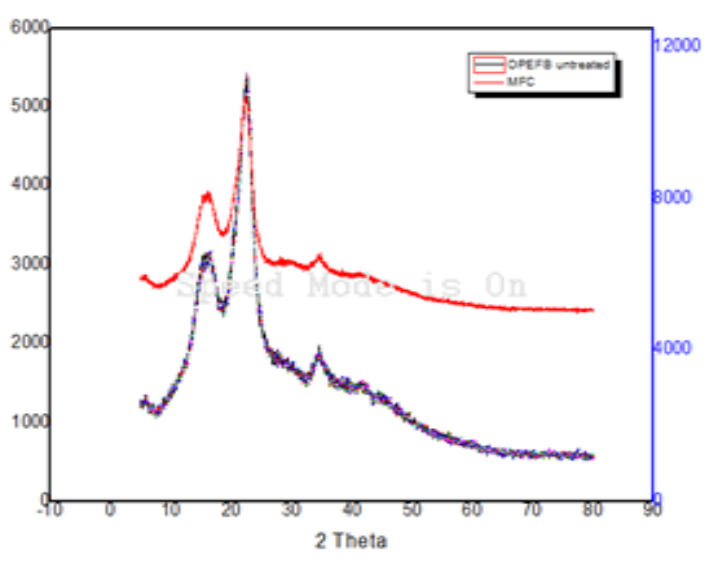

Gambar 3. Pola Difraksi Serat TKS tanpa Perlakuan dan MFC

oksalat memiliki sifat termal yang hampir mirip dengan serat rami karena pada pengujian TGA beratnya menurun secara dramatis pada suhu $310^{\circ} \mathrm{C}$ hingga $350^{\circ} \mathrm{C}$ dan dapat digunakan untuk pembuatan komposit termoseting (Mulyawan, Wibi Sana and Kaelani, 2015).

\section{X-Ray Diffraction (X-RD)}

TKS yang tidak diberi perlakuan dan TKS yang dihidrolisis oleh asam oksalat (MFC) dianalisis dengan difraksi sinar-X untuk mengevaluasi indeks kristalinitasnya. Gambar 3 menunjukkan pola difraksi x-ray yang berbeda dari antara serat TKS tanpa perlakuan dengan MFC. Puncak MFC lebih tajam dari puncak serat TKS tanpa perlakuan, yang menunjukkan peningkatan kekakuan struktur kristal dan kekuatan tarik yang lebih tinggi (Haafiz et al., 2014). Pada Gambar 3 pengamatan puncak terendah dan tertinggi serat TKS sebelum hidrolisis di $2 \mathrm{E}=15,5^{\circ}$ dan $2 \mathrm{E}=$ $22,5^{\circ}$. Untuk pengamatan terendah dan tertinggi puncak serat TKS setelah hidrolisis asam terdapat pada $2 \mathrm{E}=15,4^{\circ}$ dan $2 \mathrm{E}=22,4^{\circ}$. Berdasarkan persamaan Segal's empirics, I002 adalah maksimum difraksi laticce untuk bidang (002) berada pada sudut difraksi sekitar 2E $=200-220$, sedangkan Intensitas terendah dari bagian amorpus terjadi pada pada kisaran $2 \mathrm{E}=18$. Puncak selulosa yang khas muncul dalam kisaran $2 \mathrm{E}$ yaitu $15^{\circ} \mathrm{C}$ dan $22^{\circ} \mathrm{C}$ (Chandra, Goerge and Narayankutty, 2016). Dalam penelitian ini, nilai indeks kristal serat TKS tanpa perlakuan adalah $36,3 \%$ dan nilai indeks kristal MFC adalah $41,2 \%$. Kristalinitas tinggi menunjukkan proses pengurangan lignin dan hemiselulosa telah berhasil terjadi dan juga terjadi pengurangan area amorf pada selulosa (Burhani et al., 2017).

Hasil uji XRD ini juga sesuai dengan hasil analisis FTIR dan dapat disimpulkan bahwa pengurangan lignin, hemiselulosa, dan berbagai karakteristik kristal bersama-sama mempengaruhi aksesibilitas enzimatik ke selulosa dan kemudian indeks kristalinitas meningkat (Wang et al., 2016). Meskipun asam oksalat adalah asam lemah, tetapi dapat meningkatkan nilai kristalisasi karena proses hidrolisis dilakukan pada $80^{\circ} \mathrm{C}$ membantu memaksimalkan proses hidrolisis.

\section{Field Emission Scanning Electron Microscopy (FESEM)}

Pengujian FESEM dilakukan untuk melihat perubahan morfologi dari serat yang dihasilkan pada proses pembuatan serat. Hasil morfologi serat dari uji FESEM dapat dilihat pada Gambar 4. Setelah dilakukan pengukuran diameter serat, dihasilkan ukuran diameter serat TKS tanpa perlakukan adalah $400 \mu \mathrm{m}$ dan MFC adalah $10 \mu \mathrm{m}$. Penurunan ukuran diameter serat ini
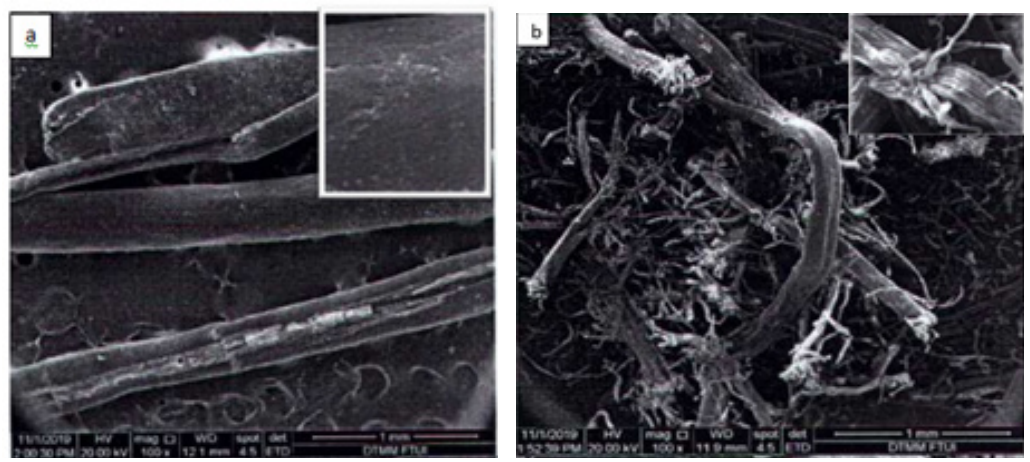

Gambar 4. Morfologi Serat (a) TKS, (b) MFC 
Tabel 2. Perbandingan Ukuran Serat MFC dari TKS dengan Proses Hidrolisis Asam Oksalat (Yuanita et al., 2015).

\begin{tabular}{lcc}
\hline Serat & \multicolumn{1}{c}{ Metode } & Diameter MFC $(\mu \mathrm{m})$ \\
\hline Ijuk & Hidrolisis asam sulfat & $5-6$ \\
Sisal & Alkali peroksida & $12,8-31$ \\
Jerami gandum & Hidrolisis NaOH & $10-15$ \\
Tebu & Hidrolisis asam nitrat & $5-10$ \\
Batang jagung & Hidrolisis asam sulfat & $5,8-7,5$ \\
Tandan Kosong Sawit (TKS) & Hidrolisis asam oksalat & 10 \\
\hline
\end{tabular}

menunjukkan bahwa penambahan basa dan $\mathrm{H}_{2} \mathrm{O}_{2}$ pada proses bleaching dan perlakuan hidrolisis asam oksalat dapat menghilangkan komponenkomponen yang terikat pada serat sehingga ukuran serat menjadi lebih kecil. Dari Gambar 4 juga dapat dilihat bahwa serat yang dihasilkan semakin terbentuk sempurna dibandingakan serat TKS tanpa perlakuan karena pada serat TKS yang tanpa perlakuan masih banyak mengandung pengotor dan paraffin yang tidak bisa dihilangkan oleh air dan hal ini sebanding dengan hasil uji nilai kristalinitas yang semakin tinggi. Nilai kristalinitas yang tinggi menunjukkan pembentukan serat semakin sempurna.

Perbandingan ukuran diameter serat MFC TKS dengan serat lainnya yang dibuat dari metode hidrolisis yang berbeda dapat dilihat pada Tabel 2. Pada Tabel 2 dapat dilihat bahwa serat MFC dari TKS dengan proses hidrolisis asam oksalat ukurannya sama dengan serat MFC dari jerami melalui proses hidrolisis $\mathrm{NaOH}$ atau serat MFC dari tebu melalui proses hidrolisis asam nitrat. Karena hal tersebut maka proses pembentukan MFC menggunakan asam oksalat dapat menghasilkan ukuran diameter serat yang setara dengan pembentukan MFC dengan proses hidrolisis basa $\mathrm{NaOH}$ dan proses hidrolisis asam nitrat.

\section{Kesimpulan}

Hasil analisis FTIR mengonfirmasi bahwa hidrolisis dengan asam oksalat dapat menurunkan kadar lignin. Proses hidrolisis dengan asam oksalat 5\% juga dapat menaikkan nilai kristalinitas dari 36,3\% menjadi 41,2\%. Hasil TGA menunjukkan hidrolisis menggunakan asam oksalat $5 \%$ dapat meningkatkan area degradasi termal, sehingga MFC hasil hidrolisis nya memiliki sifat termal sehingga yang baik dengan peningkatan area degradasi dari $280^{\circ} \mathrm{C}$ menjadi $370^{\circ} \mathrm{C}$. Hasil uji morfologi serat dengan FESEM menunjukkan bahwa serat yang dihasilkan dengan proses hidrolisis asam oksalat semakin terbentuk sempurna (fibrillated) dan ukuran diameternya pun mengecil dari $400 \mu \mathrm{m}$ menjadi $10 \mu \mathrm{m}$. Berdasarkan hasil penelitian ini, proses sintesis MFC dari serat TKS dengan hidrolisis menggunakan asam oksalat $5 \%$ adalah proses yang baik untuk pembuatan MFC dan memberikan pendekatan baru sebagai sumber MFC untuk beberapa aplikasi.

\section{Ucapan Terima Kasih}

Kami mengucapkan terima kasih kepada Ibu Wiwik Pudjiastuti selaku kepala Balai Besar Kimia dan Kemasan atas dukungan dalam pelaksanaan penelitian ini, dan kepada pihak Institut Teknologi Indonesia atas kerja sama dalam pelaksanaan penelitian ini dan juga seluruh tim yang terlibat dalam penelitian.

\section{Daftar Pustaka}

Abraham, E., Deepa, B., Pothan, L. A., Jacob, M., Thomas, S., Cvelbar, U. and Anandjiwala, R. (2011) 'Extraction of nanocellulose fibrils from lignocellulosic fibers: A novel approach', Carbohydrate Polymers. Elsevier Ltd., 86(4), pp. 1468-1475. doi: 10.1016/j. carbpol.2011.06.034.

Abraham, E., Deepa, B., Pothen, L. A., Cintil, J., Thomas, S., John, M. J., Anandjiwala, R. and Narine, S. S. (2013) 'Environmental friendly method for the extraction of coir fibre and isolation of nanofibre', Carbohydrate Polymers. Elsevier Ltd., 92(2), pp. 14771483. doi: 10.1016/j.carbpol.2012.10.056. 
Ahmad, Y., Laksmi, M., Heny, P. and Lingga, A. (2015) 'Uji Karakterisasi Mikrokristalin Selulosa dari Nata De Soya Sebagai Eksipien Tablet', Farmasains, 6(2), p. $269: 274$.

Barlianti, V., Dahnum, D., Hendarsyah, H. and Abimanyu, H. (2015) 'Effect of Alkaline Pretreatment on Properties of Lignocellulosic Oil Palm Waste', Procedia Chemistry, 16, pp. 195-201. doi: 10.1016/j. proche.2015.12.036.

Burhani, D., Putri, A. M. H., Waluyo, J., Nofiana, Y. and Sudiyani, Y. (2017) 'The effect of two-stage pretreatment on the physical and chemical characteristic of oil palm empty fruit bunch for bioethanol production', AIP Conference Proceedings, 1904. doi: 10.1063/1.5011873.

Chandra, J., Goerge, C. and Narayankutty, S. K. (2016) 'Isolation and Characterization of Cellulose Nanofibrils from Arecanut Husk Fibre', Carbohydrate Polymers, 142, pp. 158-166. Available at: https://doi. org/101016/j.carbpor.2016.01.05.

Chen, W., Yu, H., Liu, Y., Hai, Y., Zhang, M. and Chen, P. (2011) 'Isolation and characterization of cellulose nanofibers from four plant cellulose fibers using a chemicalultrasonic process', Cellulose, 18(2), pp. 433-442. doi: 10.1007/s10570-011-9497-z.

Dewanti, D. P. (2018) 'Potensi Selulosa dari Limbah Tandan Kosong Kelapa Sawit untuk Bahan Baku Bioplastik Ramah Lingkungan', Jurnal Teknologi Lingkungan, 19(1), p. 81. doi: 10.29122/jtl.v19i1.2644.

Haafiz, M., Hassan, A., Zakaria, Z. and Inuwa, I. M. (2014) 'Isolation and Characterization of Cellulose Nanowhiskers from Oil Palm Biomass Microcrystalline Cellulose', Carbohydrate Polymers, 1(103), pp. 119125.

Ismojo, Simanulang, P. H., Zulfia, A. and Chalid, M. (2017) 'Preparation of micro-fibrillated cellulose from sorghum fibre through alkalization and acetylation treatments', IOP Conference Series: Materials Science and Engineering, 223(1). doi: 10.1088/1757$899 X / 223 / 1 / 012057$.

Lavoine, N., Desloges, I., Dufresne, A. and Bras, J. (2012) 'Microfibrillated cellulose - Its barrier properties and applications in cellulosic materials: Areview', Carbohydrate Polymers. Elsevier Ltd., 90(2), pp. 735-764. doi: 10.1016/j.carbpol.2012.05.026.

Mulyawan, A. S., Wibi Sana, A. and Kaelani, Z. (2015) 'Identification of Physical and Thermal Properties of', Arena Tekstil, 30(1), pp. 75-82.
Osvaldo, Z. S., Panca Putra, S. and Faizal, M. (2012) 'Pengaruh Konsentrasi Asam dan Waktu pada Proses Hidrolisis dan Fermentasi Pembuatan Biotenaol dari Alang-alang', Jurnal Teknik Kimia, 18(2), pp. 52-62.

Rezayati Charani, P., Dehghani-Firouzabadi, M., Afra, E., Blademo, Å., Naderi, A. and Lindström, T. (2013) 'Production of microfibrillated cellulose from unbleached kraft pulp of Kenaf and Scotch Pine and its effect on the properties of hardwood kraft: Microfibrillated cellulose paper', Cellulose, 20(5), pp. 2559-2567. doi: 10.1007/s10570013-9998-z.

Syahbanu, I., Anugraini, A. and Melati, H. A. (2018) 'Kinetika Degradasi Selulosa Asetat dari Sabut Pinang', Indonesian Journal of Pure and Applied Chemistry, 1(1), pp. 2429.

Syverud, K. and Stenius, P. (2009) 'Strength and barrier properties of MFC films', Cellulose, 16(1), pp. 75-85. doi: 10.1007/s10570-0089244-2.

Tristantini, D., Dewanti, D. P. and Sandra, C. (2017) 'Isolation and characterization of $\alpha$-cellulose from blank bunches of palm oil and dry jackfruit leaves with alkaline process $\mathrm{NaOH}$ continued with bleaching process H2O2', AIP Conference Proceedings, 1904. doi: $10.1063 / 1.5011858$.

Wang, W., Zhuang, X., Yuan, Z., Qi, W. and Wang, Q. (2016) 'Structural Changes of Lignin after Liquid Hot Water Pretreatment and Its Effect on the Enzymatic Hydrolysis', BioMed Research International, 3(21), pp. 23-31. Available at: https://doi. org/10.1155/2016/8568604.

Xu, W., Grénman, H., Liu, J., Kronlund, D., Li, B., Backman, P., Peltonen, J., Willför, S., Sundberg, A. and Xu, C. (2017) 'Mild Oxalic-Acid-Catalyzed Hydrolysis as a Novel Approach to Prepare Cellulose Nanocrystals', ChemNanoMat, 3(2), pp. 109-119. doi: 10.1002/cnma.201600347.

Yasa, I. W. S. et al. (2020) 'Sifat Fisik Dan Mekanis Lembaran Kering Selulosa Bakteri Berbahan Dasar Limbah Hasil Pertanian', Jurnal Ilmiah Rekayasa Pertanian dan Biosistem, 8(1), pp. 89-99. doi: 10.29303/ jrpb.v8i1.170.

Yuanita, E., Pratama, J. N., Mustafa, J. H. and Chalid, M. (2015) 'Multistages Preparation for Microfibrillated Celluloses Based on Arenga Pinnata "ijuk" fiber', Procedia Chemistry, 16, pp. 608-615. doi: 10.1016/j. proche.2015.12.099. 
- Halaman ini sengaja dikosongkan - 